\title{
Effects of Enkephalins and Two Enzyme Resistant Analogues on Monoamine Synthesis and Metabolism in Rat Brain*
}

\author{
J. A. García-Sevilla**, T. Magnusson, and A. Carlsson \\ Department of Pharmacology, University of Göteborg, Fack, S-40033 Göteborg, Sweden
}

Summary. Methionine-enkephalin and leucineenkephalin, administered into the lateral ventricle of intact rats, increased the accumulation of DOPA by a naloxone-sensitive mechanism in different brain regions after inhibition of the aromatic L-amino acid decarboxylase. Because of the rapid enzymatic degradation of both enkephalins large doses $(500 \mu \mathrm{g})$ were required to enhance brain catecholamine synthesis. The two enzyme resistant enkephalin analogues $\mathrm{D}-\mathrm{Ala}^{2}$ methionine enkephalin amide (DALA (4-256 $\mu \mathrm{g})$ and FK 33-824 $(0.003-1 \mu \mathrm{g})$ also increased the synthesis of DOPA, dose-dependently and by naloxone-sensitive mechanisms, but at much lower dosage level. The enkephalins markedly enhanced the brain tyrosine concentration but this effect was not antagonized by naloxone, probably because the enzymatic cleavage releases tyrosine from the administered peptides. In contrast, neither DALA nor FK 33-824 increased the brain tyrosine concentration. The formation of 5-HTP and the brain tryptophan concentration were also increased by the enkephalins, although these effects were not blocked by naloxone. The enkephalin analogues, however, enhanced the formation of 5-HTP and the brain tryptophan concentration by naloxonesensitive mechanisms. All four peptides accelerated the disappearance of dopamine, noradrenaline and 5hydroxytryptamine after inhibition of monoamine synthesis. The results suggest that endogenous enkephalins, through the activation of opiate receptors, are involved in the short-term regulation of central monoaminergic systems.

Send offprint requests to $\mathrm{T}$. Magnusson at the above address

* Preliminary data were presented at the Nobel Symposium 42, "Principles for the Central Regulation of the Endocrine System", Stockholm, June 8-10, 1978, and at the 4th International Catecholamine Symposium, Asilomar Conference Center, Pacific Grove, California, September 17-22, 1978

** Present address: Department of Pharmacology, The University of Michigan Medical School, M6322 Medical Science Building, Ann Arbor, Michigan 481 09, USA
Key words: Methionine-enkephalin - Leucineenkephalin - Tyr-D-Ala-Gly-Phe-Met-NH $\mathrm{NH}_{2}$ (DALA) - Tyr-D-Ala-Gly-MePhe-Met(O)-ol (FK 33-824) Monoamine synthesis and metabolism - Rat brain.

\section{Introduction}

The enkephalins, methionine $\left(\mathrm{Met}^{5}\right)$-enkephalin $(\mathrm{H}-$ Tyr-Gly-Gly-Phe-Met-OH) and leucine ( $\mathrm{Leu}^{5}$ )-enkephalin (H-Tyr-Gly-Gly-Phe-Leu-OH), are naturally occurring peptides with morphine-like pharmacological properties which have recently been isolated and characterized from mammalian brain (Hughes et al., 1975). Both pentapeptides are widely though unevently distributed in the central nervous system (Hong et al., 1977; Hughes et al., 1977), and their similar regional distributions closely parallel that of the opiate receptor (for a review see Snyder and Simantov, 1977). Moreover, they are subcellularly located in synaptosomal and microsomal fractions (Osborne et al., 1978a) and their in vitro release from brain slices and synaptosomal preparations by a calcium-dependent process have been reported (Henderson et al., 1978; Iversen et al., 1978; Osborne et al., 1978b). All these observations suggest that the enkephalins play a neurotransmitter/ neuromodulator role in the central nervous system (for a review see Frederickson, 1977).

It is well established that morphine and other narcotic analgesics modulate the brain dopamine turnover by a naloxone-sensitive mechanism (Kuschinsky, 1976). We have recently reported (García-Sevilla et al., 1978 ) that the acute administration of the opiatereceptor agonists, morphine and $\beta$-endorphin, increase the synthesis of dopamine and serotonin in the brain of intact rats, while the opiate-receptor antagonists, naloxone and naltrexone have opposite effects. These data suggest that the opiate receptors and their en- 
dogenous ligands are involved in the short-term regulation of both neurotransmitters.

Consequently, the present investigation was carried out to assess the effects of the enkephalins on brain monoamine turnover. Because of the rapid degradation of both $\mathrm{Met}^{5}$ - and $\mathrm{Leu}^{5}$-enkephalins by brain peptidases (Meek et al., 1977; Dupont et al., 1977), the effects of two metabolically stable synthetic analogues, D-Ala ${ }^{2}$-methionine enkephalin amide (Pert et al., 1976) and the FK 33-824 compound (Roemer et al., 1977), were also studied.

\section{Materials and Methods}

Animals. Male Sprague-Dawley rats weighing 200-250 g (Anticimex, Stockholm, Sweden) were used. The animals received a standard diet with water freely available and were housed at $24^{\circ} \mathrm{C}$ under a $12 \mathrm{~h}$ lightdark cycle.

Drugs. 3-Hydroxybenzylhydrazine $\mathrm{HCl}$ (NSD 1015, synthesized in this institute by Dr. P. Lindberg) and $\mathrm{N}$-(DL-seryl)- $\mathrm{N}^{2}-(2,3,4-$ trihydroxybenzyl)hydrazine (Ro4-4602 or benserazide, F. Hoffmann-La Roche Co., Basle, Switzerland) were dissolved in $0.9 \%$ $\mathrm{w} / \mathrm{v} \mathrm{NaCl}$ solution (saline) and injected intraperitoneally (i. p.) $\mathrm{Met}^{5}-$ enkephalin, Leu ${ }^{5}$-enkephalin and $\mathrm{D}-\mathrm{Ala}^{2}$-methionine enkephalin amide (DALA) (purchased from Serva Feinbiochemica, Heidelberg, FRG) and D-Ala ${ }^{2}, \mathrm{MePhe}^{4}, \mathrm{Met}(\mathrm{O})^{5}$-ol-enkephalin (FK 33-824) (gift from Dr. Roemer, Sandoz Ltd., Basle, Switzerland) were dissolved in saline and injected intracerebroventricularly (i.c.v.). Naloxone (gift from Dr. Ferster, Endo Laboratories, Inc.) was dissolved in saline and injected i.p. or s.c. The time and dose schedules for injections are given in the Results section. Control rats always received the same number of injections of saline at the same time intervals as the experimental animals.

Implantation of Intracerebroventricular Cannulae. A polyethylene cannula was permanently implanted into each lateral ventricle as described in detail previously (García-Sevilla et al., 1978). The experiments were performed 2 days after the operation when the gross behaviour of the animals was normal. The proper position of the cannulae was checked at autopsy.

Synthesis of Brain Monoamines. The in-vivo activity of tyrosine and tryptophan hydroxylase, rate-limiting enzymes in the synthesis of monoamines, were studied by measuring the accumulation of 3,4dihydroxyphenylalanine (DOPA) and 5-hydroxytryptophan (5HTP) within $30 \mathrm{~min}$ after inhibition of the aromatic L-amino acid decarboxylase by a supramaximal dose of NSD $1015(100 \mathrm{mg} / \mathrm{kg})$ (Carlsson et al., 1972). The enkephalins $(500 \mu \mathrm{g})$, DALA (4-256 $\mu \mathrm{g})$ and FK 33-824 (3 $\mathrm{ng}-1 \mu \mathrm{g})$ were injected i.c. v.; half of the dose was given into the right lateral ventricle followed within $1 \mathrm{~min}$ by the same amount into the left lateral ventricle $(10 \mu l$ of peptide solution followed by $5 \mu$ l of saline into each ventricle). Control rats received $15 \mu \mathrm{l}$ of saline into each ventricle. The aim of these experiments was to study the effects of enkephalins and analogues on the rate of formation of noradrenaline, dopamine and 5-hydroxytryptamine.

Utilization of Brain Monoamines. The utilization of noradrenaline, dopamine and 5-hydroxytryptamine (5-HT) was determined by the disappearance of the amines after inhibition of synthesis by another inhibitor of the aromatic L-amino acid decarboxylase, benserazide $(800 \mathrm{mg} / \mathrm{kg}$, i. p.) (Andén et al., 1967). Immediately after the administration of this inhibitor, the enkephalins $(500 \mu \mathrm{g})$, DALA $(50 \mu \mathrm{g})$ or FK 33-824 $(1 \mu \mathrm{g})$ were injected i.c.v. followed after $25 \mathrm{~min}$ by a second dose representing $40 \%$ of the first one (see above). Control animals received the same volume of saline. The rats were decapitated
$60 \mathrm{~min}$ after the injection of benserazide. This experiment was designed to investigate the influence of enkephalins and analogues on the rate of disappearance of monoamines after inhibition of synthesis. This disappearance rate is largely dependent on the rate of nerve impulse flow (Andén et al., 1969).

Dissection of the Brain. After decapitation of the rats the brains were quickly removed and dissected on an ice-cold plate into the following parts: (1) limbic forebrain containing certain dopamine-rich structures e.g. the olfactory tubercle, nucleus accumbens (medial part), nucleus amygdaloideus centralis and part of the paleocortex, (2) corpus striatum, (3) the remainder of the hemispheres including hippocampus (referred to as hemispheres), (4) diencephalon and (5) lower brain stem. Dopamine is the predominating catecholamine in parts (1) and (2) and noradrenaline in parts (3), (4) and (5). For details of dissection see Carlsson and Lindqvist (1973). The dissected brain parts were immediately frozen on dry ice and the parts of two brains were pooled, weighed and stored at $-80^{\circ} \mathrm{C}$. In the experiments of utilization of brain monoamines, whole brains were used for assay.

Biochemical Assays. After thawing, the pooled brain parts or the whole brains were homogenized in $10 \mathrm{ml}$ of $0.4 \mathrm{~N}$ perchloric acid containing $5 \mathrm{mg}$ sodium metabisulphite and $20 \mathrm{mg}$ EDTA (final volume $10.3 \mathrm{ml}$ ). The homogenates were centrifuged at about $10,000 \mathrm{~g}$ for $10 \mathrm{~min}$ at $0^{\circ} \mathrm{C}$ and the supernatant purified on a strong cation exchange column (Dowex $50 \mathrm{~W}, \mathrm{X}-4)$ (Kehr et al., 1972; Atack and Magnusson, 1978). The following spectrophotofluorimetric analysis were performed: tyrosine (Waalkes and Udenfriend, 1957), DOPA (Kehr et al., 1972), tryptophan (Bédard et al., 1972), 5-HTP (Atack and Lindquist, 1973), dopamine (Atack, 1973), noradrenaline (Bertler et al., 1958; Kehr et al., 1976), 5-HT and 5-hydroxyindoleacetic acid (5-HIAA) (Atack and Lindqvist, 1973).

Statistics. One-way analysis of variance followed by $t$-test, using the within groups variance, was used. The level of significance was chosen as $P=0.05$.

\section{Results}

Effects of the Enkephalins

and their Synthetic Analogues DALA

and FK 33-824 on Tyrosine Hydroxylase

Activity in vivo

The i.c.v. injection of either $\mathrm{Met}^{5}$ - and $\mathrm{Leu}^{5}$ enkephalin $(500 \mu \mathrm{g} / \mathrm{rat})$ enhanced the formation of DOPA in the brain of rats treated with the aromatic Lamino acid decarboxylase inhibitor, NSD 1015 (Table 1). In the various brain regions, however, the increases induced by Leu ${ }^{5}$-enkephalin $(35-65 \%)$ were significantly higher than those of $\mathrm{Met}^{5}$-enkephalin $(10-35 \%)$. As expected, naloxone $(10 \mathrm{mg} / \mathrm{kg})$, a pure opiate receptor antagonist, blocked these increases in all brain regions, except in the lower brain stem for $\mathrm{Met}^{5}$-enkephalin (Table 1). The two enzyme resistant enkephalin analogues DALA and FK 33-824 caused the same effect but with the expected differences in potency. Thus, the i.c. v. administration of DALA (4$256 \mu \mathrm{g} / \mathrm{rat})$ and FK $33-824(0.003-1 \mu \mathrm{g} / \mathrm{rat})$ significantly increased the synthesis of DOPA in a dosedependent manner and by a naloxone-sensitive mechanism (Figs. 1 and 2). As the figures show, the log dose-response curves for the two enkephalin analogues 
Table 1. Effects of enkephalins on DOPA formation in rat brain regions. The enkephalins $(500 \mu \mathrm{g} / \mathrm{rat})$ were injected intracerebroventricularly (i.c. v.) $10 \mathrm{~min}$ before NSD 1015 (3-hydroxybenzylhydrazine; $100 \mathrm{mg} / \mathrm{kg}$ i.p.) and the rats were killed after another $30 \mathrm{~min}$. Control rats received i.c. v. the same volume of saline $10 \mathrm{~min}$ before the NSD 1015 . Naloxone $(10 \mathrm{mg} / \mathrm{kg})$ was given either s.c. and 30 min before Met ${ }^{5}$-enkephalin or i.p. and $60 \mathrm{~min}$ before Leu ${ }^{5}$-enkephalin. Shown are the means \pm S.E.M. with the number of experiments in parentheses

\begin{tabular}{|c|c|c|c|c|c|}
\hline \multirow[t]{2}{*}{ Enkephalin } & \multicolumn{5}{|l|}{ DOPA $(\mathrm{ng} / \mathrm{g})$} \\
\hline & $\begin{array}{l}\text { Limbic } \\
\text { regions }\end{array}$ & $\begin{array}{l}\text { Corpus } \\
\text { striatum }\end{array}$ & Hemispheres & Diencephalon & $\begin{array}{l}\text { Lower } \\
\text { brain stem }\end{array}$ \\
\hline Control & $426 \pm 16(8)$ & $591 \pm 29(7)$ & $71 \pm 4(8)$ & $261 \pm 12(8)$ & $137 \pm 6(8)$ \\
\hline $\begin{array}{l}\text { Met }^{5} \text {-enkephalin } \\
\text { Met }^{5} \text {-enkephalin }\end{array}$ & $510 \pm 33(6)^{*}$ & $649 \pm 32(6)$ & $95 \pm 6(6)^{* *}$ & $292 \pm 27(6)$ & $170 \pm 9(6)^{*}$ \\
\hline plus naloxone & $431 \pm 14(2)$ & $514 \pm 28(2)$ & $77 \pm 2(2)$ & $252 \pm 13(2)$ & $213 \pm 31(2)^{* * *}$ \\
\hline $\mathrm{Leu}^{5}$-enkephalin & $603 \pm 35(4)^{* * * *}$ & $898 \pm 44(4)^{* * *}$ & $117 \pm 10(4)^{* * * *}$ & $351 \pm 16(4)^{* *}$ & $209 \pm 16(4)^{* * *}$ \\
\hline $\begin{array}{l}\mathrm{Leu}^{5} \text {-enkephalin } \\
\text { plus naloxone }\end{array}$ & $361 \pm 29(2)$ & $617 \pm 48(2)$ & $72 \pm 9(2)$ & $236 \pm 15(2)$ & $133 \pm 8(2)$ \\
\hline $\begin{array}{l}\mathrm{Leu}^{5} \text { - vs Met } \\
\text { enkephalin }\end{array}$ & $P<0.05$ & $P<0.001$ & $P<0.05$ & NS & $P<0.025$ \\
\hline
\end{tabular}

Statistical significances were calculated according to one way analysis of variance followed by $t$-test. Differs from control: ${ }^{*} P<0.05$; ** $P<0.01 ; * * * P<0.001$

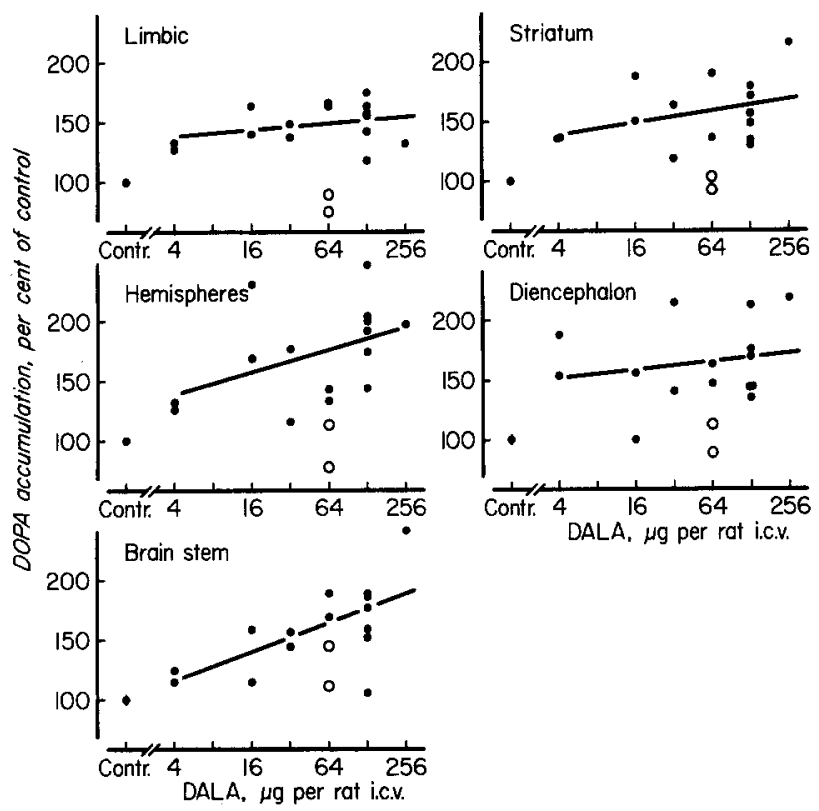

Fig. 1. Dose-response curves for the effect of $\mathrm{D}-\mathrm{Ala}^{2}$-methionine enkephaline amide (DALA) on DOPA accumulation in rat brain regions after decarboxylase inhibition. DALA was injected i.c.v. $10 \mathrm{~min}$ before NSD $1015(100 \mathrm{mg} / \mathrm{kg}$, i.p.) and the rats were killed after another $30 \mathrm{~min}$. Control rats received i.c.v. the same volume of saline $10 \mathrm{~min}$ before NSD 1015. The results are given in per cent of saline-treated control groups, each point comprising 2 pooled brain parts, Mean control values \pm S.E.M. $(n=14)$ in $n g / g$; limbic forebrain : $427 \pm 14$; corpus striatum: $543 \pm 16$; hemispheres : $78 \pm 2$; diencephaton: $216 \pm 9$; lower brain stem: $125 \pm 5$. Open symbols represent rats pretreated with naloxone $(10 \mathrm{mg} / \mathrm{kg}$, s.c.) $30 \mathrm{~min}$ before DALA. Lines are calculated regression lines

seem to be approximately linear within the dose range studied. Significant correlation coefficients were obtained for FK 33-824 ( $r=0.84-0.96, P<0.001)$ with the exception of the lower brain stem (Fig. 2), whereas

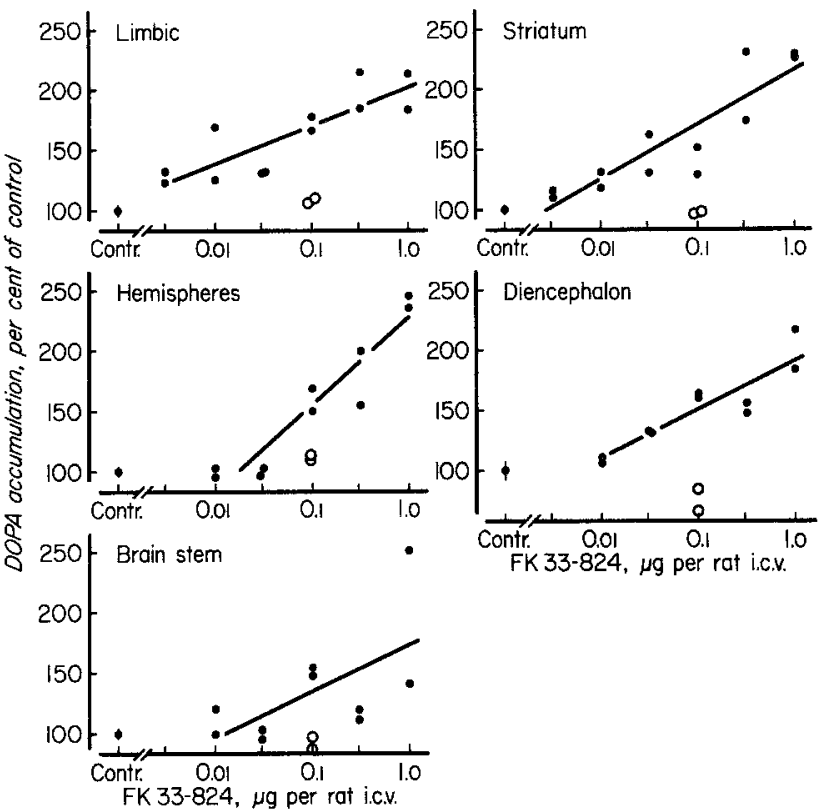

Fig.2. Dose-response curves for the effect of $\mathrm{D}-\mathrm{Ala}^{2}-\mathrm{MePhe}^{4}-$ Met $(\mathrm{O})^{5}$-ol-enkephalin (FK 33-824) on DOPA accumulation in rat brain regions after decarboxylase inhibition. FK 33-824 was injected i.c.v. $10 \mathrm{~min}$ before NSD $1015(100 \mathrm{mg} / \mathrm{kg}$, i.p.) and the rats were killed after another $30 \mathrm{~min}$. Control rats received i.c.v. the same volume of saline $10 \mathrm{~min}$ before NSD 1015. The results are given in per cent of saline-treated control groups, each point comprising 2 pooled brain parts. Mean control values \pm S.E.M. $(n=10)$ in $\mathrm{ng} / \mathrm{g}$; limbic forebrain: $378 \pm 16$; corpus striatum: $507 \pm 17$; hemispheres: $61 \pm 2$; diencephalon: $239 \pm 16$; lower brain stem: $131 \pm 5$. Open symbols represent rats pretreated with naloxone $(10 \mathrm{mg} / \mathrm{kg}$, s.c.) $1 \mathrm{~min}$ before FK 33-824. Lines are calculated regression lines

for DALA statistical significance was reached only in the latter region $(r=0.65, P<0.01$; Fig. 1$)$.

The four opioid peptides differed largely in potency, FK 33-824 being about $100-1,000$ times more potent 
Table 2. Effects of enkephalins and synthetic analogues D-Ala ${ }^{2}$-methionine enkephalin amide (DALA) and D-Ala ${ }^{2}, \mathrm{MePhe}^{4}, \mathrm{Met}(\mathrm{O})^{5}{ }^{5}-\mathrm{ol}-$ enkephalin (FK 33-824) on the concentration of tyrosine in rat brain regions. The enkephalins ( $500 \mu \mathrm{g} / \mathrm{rat})$ and the synthetic analogues DALA $(125 \mu \mathrm{g} / \mathrm{rat})$ and FK $33-824(1 \mu \mathrm{g} / \mathrm{rat})$ were injected intracerebroventricularly (i.c.v.) $10 \mathrm{~min}$ before NSD 1015 (3-hydroxybenzylhydrazine; $100 \mathrm{mg} / \mathrm{kg}$ i.p.) and the rats were killed after another $30 \mathrm{~min}$. Control rats received i.c. v. the same volume of saline $10 \mathrm{~min}$ before the NSD 1015 . Naloxone $(10 \mathrm{mg} / \mathrm{kg})$ was given either s.c. $30 \mathrm{~min}$ before $\mathrm{Met}^{5}$-enkephalin or i.p. $60 \mathrm{~min}$ before Leu ${ }^{5}$-enkephalin. Shown are the means \pm S.E.M. with the number of experiments in parentheses

\begin{tabular}{|c|c|c|c|c|c|}
\hline \multirow[t]{2}{*}{ Enkephalin } & \multicolumn{5}{|l|}{ Tyrosine $(\mu \mathrm{g} / \mathrm{g})$} \\
\hline & $\begin{array}{l}\text { Limbic } \\
\text { regions }\end{array}$ & $\begin{array}{l}\text { Corpus } \\
\text { striatum }\end{array}$ & Hemispheres & Diencephalon & $\begin{array}{l}\text { Lower } \\
\text { brain stem }\end{array}$ \\
\hline Control & $20.4 \pm 0.6(18)$ & $20.0 \pm 0.6(18)$ & $21.3 \pm 0.6(18)$ & $19.5 \pm 0.5(18)$ & $18.0 \pm 0.4(18)$ \\
\hline Met ${ }^{5}$-enkephalin & $38.0 \pm 1.4(6)^{* * *}$ & $25.6 \pm 1.3(6)^{* * *}$ & $50.2+3.3(6)^{* * *}$ & $46.7 \pm 4.5(6)^{* * *}$ & $39.3 \pm 3.7(6)^{* * *}$ \\
\hline \multicolumn{6}{|l|}{ Met $^{5}$-enkephalin } \\
\hline plus naloxone & $41.0 \pm 1.2(2)^{* * *}$ & $26.0 \pm 4.1(2)^{*}$ & $49.2 \pm 6.9(2)^{* * *}$ & $51.2 \pm 3.5(2)^{* * *}$ & $47.3 \pm 4.1(2)^{* * *}$ \\
\hline Leu $^{5}$-enkephalin & $30.4 \pm 1.9(4)^{* * *}$ & $22.3 \pm 2.3(4)$ & $36.1 \pm 4.2(4)^{* * *}$ & $33.6 \pm 1.6(4)^{* * *}$ & $29.4 \pm 1.7(4)^{* * *}$ \\
\hline \multicolumn{6}{|l|}{$\mathrm{Leu}^{5}$-enkephalin } \\
\hline plus naloxone & $29.9 \pm 2.3(2)^{* * *}$ & $21.3 \pm 0.2(2)$ & $29.8 \pm 2.5(2)^{*}$ & $27.3 \pm 4.2(2)^{*}$ & $24.3 \pm 1.0(2)^{* * *}$ \\
\hline DALA & $21.7 \pm 1.4(5)$ & $19.4 \pm 0.8(5)$ & $21.6 \pm 1.8(5)$ & $21.7 \pm 1.7(5)$ & $18.6 \pm 1.5(5)$ \\
\hline FK 33-824 & $21.0 \pm 1.7(2)$ & $19.8 \pm 1.7(2)$ & $20.6 \pm 3.1(2)$ & $19.8 \pm 1.2(2)$ & $17.4 \pm 3.0(2)$ \\
\hline \multicolumn{6}{|l|}{$\mathrm{Met}^{5}-\mathrm{vs} \mathrm{Leu}^{5}-$} \\
\hline enkephalin & $P<0.001$ & NS & $P<0.001$ & $P<0.001$ & $P<0.005$ \\
\hline
\end{tabular}

Statistical significances were calculated according to one way analysis of variance followed by $t$-test. Differs from control: ${ }^{*} P<0.05$; $* * * P<0.001$

than DALA in the various brain regions, and the latter about 100 times more potent than the enkephalins. In the limbic forebrain, a dopamine-rich area, $3 \mathrm{ng} / \mathrm{rat}$ of the FK 33-824 compound was the minimal effective dose which significantly increased the formation of DOPA after decarboxylase inhibition $(43 \%$; $P<0.001$ ) (Fig. 2). This enkephalin analogue also proved active in increasing DOPA accumulation $(22 \%$; $P<0.05$ ) in the limbic forebrain after systemic administration $\left(5 \mathrm{mg} / \mathrm{kg}\right.$; s.c.). Both $\mathrm{Met}^{5}$ - and $\mathrm{Leu}^{5}$ enkephalin markedly increased the brain tyrosine concentrations in all brain regions, except in the corpus striatum where the effect was modest (Table 2). In the various brain regions the increases induced by $\mathrm{Met}^{5}$ enkephalin $(85-140 \%)$ were significantly higher than those of Leu ${ }^{5}$-enkephalin $(50-70 \%)$. For both peptides this effect was not antagonized by naloxone $(10 \mathrm{mg} / \mathrm{kg})$. In contrast to the enkephalins, neither DALA $(125 \mu \mathrm{g} / \mathrm{rat})$ nor FK 33-824 (1 $\mu \mathrm{g} / \mathrm{rat})$ increased the brain tyrosine concentration (Table 2).

\section{Effects of the Enkephalins \\ and their Synthetic Analogues DALA \\ and FK 33-824 on Tryptophan Hydroxylase Activity in vivo}

The i.c.v. injection of $\mathrm{Met}^{5}$ - or $\mathrm{Leu}^{5}$-enkephalin $(500 \mu \mathrm{g} / \mathrm{rat})$ enhances 5 -HTP formation in several brain parts of rats treated with NSD 1015 (Table 3). Leu ${ }^{5}$ enkephalin was ineffective in the limbic forebrain, corpus striatum and hemispheres, whereas $\mathrm{Met}^{5}$ enkephalin induced a small but significant increase
$(10-15 \%)$ in the two last mentioned brain regions. In the diencephalon and in the lower brain stem the enkephalins consistently increased the synthesis of 5HTP and for the both peptides this effect was of the same magnitude $(20-30 \%)$. Unexpectedly, the increases in 5-HTP formation induced by $\mathrm{Met}^{5}$ - and $\mathrm{Leu}^{5}$-enkephalin were not blocked by naloxone $(10 \mathrm{mg} / \mathrm{kg})$ (Table 3$)$.

The DALA analogue $(125 \mu \mathrm{g} / \mathrm{rat})$ increased the formation of 5-HTP in the diencephalon and in the lower brain stem to about the same extent $(20 \%)$, as did the enkephalins, but had a stronger effect than the natural enkephalins in the limbic forebrain, corpus striatum and hemispheres $(20-60 \%$ ) (Table 4$)$. Lower doses of DALA were ineffective in enhancing 5-HTP accumulation after decarboxylase inhibition (data not shown). The FK 33-824 compound moderately increased the synthesis of 5-HTP in various brain regions $(10-25 \%$, Table 4$)$. In contrast to the enkephalins the increases in 5-HTP formation induced by the synthetic analogues were completely blocked by the previous administration of naloxone $(10 \mathrm{mg} / \mathrm{kg})$ (Table 4$)$.

Table 5 shows the effects of the enkephalins and the synthetic analogues on tryptophan concentrations in the various rat brain regions. The increases induced by $\mathrm{Met}^{5}$ - and $\mathrm{Leu}^{5}$-enkephalin $(15-50 \%)$ were at most partially blocked by naloxone $(10 \mathrm{mg} / \mathrm{kg})$, whereas those induced by DALA $(20 \%)$ were blocked by the opiate receptor antagonist. The FK 33-824 compound did not increase the tryptophan concentrations in any brain region, except in the limbic forebrain $(17 \%$; $P<0.05$ ) (Table 5). 
Table 3. Effects of enkephalins on 5-hydroxytryptophan (5-HTP) formation in rat brain regions. The enkephalins (500 $\mu \mathrm{g} / \mathrm{rat})$ were injected intracerebroventricularly (i.c.v.) $10 \mathrm{~min}$ before NSD 1015 (3-hydroxybenzylhydrazine; $100 \mathrm{mg} / \mathrm{kg}$ i.p.) and the rats were killed after another $30 \mathrm{~min}$. Control rats received i.c.v. the same volume of saline $10 \mathrm{~min}$ before the NSD 1015 . Naloxone $(10 \mathrm{mg} / \mathrm{kg}$ ) was given either s.c. and $30 \mathrm{~min}$ before $\mathrm{Met}^{5}$-enkephalin or i.p. and $60 \mathrm{~min}$ before $\mathrm{Leu}^{5}$-enkephalin. Shown are the means \pm S.E.M. with the number of experiments in parentheses

\begin{tabular}{|c|c|c|c|c|c|}
\hline \multirow[t]{2}{*}{ Enkephalin } & \multicolumn{5}{|c|}{ 5-HTP (ng/g) } \\
\hline & $\begin{array}{l}\text { Limbic } \\
\text { regions }\end{array}$ & $\begin{array}{l}\text { Corpus } \\
\text { striatum }\end{array}$ & Hemispheres & Diencephalon & $\begin{array}{l}\text { Lower } \\
\text { brain stem }\end{array}$ \\
\hline Control & $98 \pm 5(8)$ & $55 \pm 2(8)$ & $49 \pm 2(8)$ & $135 \pm 7(8)$ & $167 \pm 4(8)$ \\
\hline $\mathrm{Met}^{5}$-enkephalin & $108 \pm 9(6)$ & $64 \pm 2(6)^{* *}$ & $55 \pm 2(6)^{*}$ & $163 \pm 7(6)^{* * *}$ & $208 \pm 4(6)^{* * *}$ \\
\hline $\begin{array}{l}\text { Met }^{5} \text {-enkephalin } \\
\text { plus naloxone }\end{array}$ & $105 \pm 2(2)$ & $66 \pm 2(2)^{*}$ & $65 \pm 1(2)^{* * * * *}$ & $168 \pm 5(2)^{*}$ & $210 \pm 4(2)^{* * *}$ \\
\hline $\begin{array}{l}\text { Leu }^{5} \text {-enkephalin } \\
\text { Leu }^{5} \text {-enkephalin }\end{array}$ & $106 \pm 2(4)$ & $59 \pm 2(4)$ & $51 \pm 2(4)$ & $175 \pm 4(4)^{* *}$ & $199 \pm 9(4)^{* * *}$ \\
\hline plus naloxone & $112 \pm 3(2)$ & $53 \pm 5(2)$ & $61 \pm 0(2)^{* *}$ & $169 \pm 7(2)^{*}$ & $189 \pm 1(2)^{*}$ \\
\hline
\end{tabular}

Statistical significances were calculated according to one way analysis of variance followed by $t$-test. Differs from control: $* P<0.05$; ** $P<0.01 ; * * * P<0.001$

Table 4. Effects of enkephalin analogues D-Ala ${ }^{2}$-methionine enkephalin amide (DALA) and D-Ala ${ }^{2}$, MePhe ${ }^{4}$, Met(O) ${ }^{5}$-ol-enkephalin (FK 33824) on 5-hydroxytryptophan (5-HTP) formation in rat brain regions. DALA (125 $\mu \mathrm{g} / \mathrm{rat}$ ) and FK 33-824 (pooled data from 0.01,0.1,0.3 and $1 \mu \mathrm{g} / \mathrm{rat}$ ) were injected intracerebroventricularly (i.c.v.) $10 \mathrm{~min}$ before NSD 1015 (3-hydroxybenzylhydrazine, $100 \mathrm{mg} / \mathrm{kg}$ i.p.) and the rats were killed after another $30 \mathrm{~min}$. Control rats received i.c. v. the same volume of saline $10 \mathrm{~min}$ before NSD 1015 . Naloxone $(10 \mathrm{mg} / \mathrm{kg})$ was given either i. p. and $60 \mathrm{~min}$ before DALA or s.c. and $1 \mathrm{~min}$ before FK 33-824 (0.1 $\mathrm{gg} / \mathrm{rat})$. Shown are the means \pm S.E.M. with the number of experiments in parentheses

\begin{tabular}{lcllll}
\hline Enkephalin & \multicolumn{2}{l}{5 -HTP $(\mathrm{ng} / \mathrm{g})$} & & & \\
\cline { 2 - 5 } & $\begin{array}{l}\text { Limbic } \\
\text { regions }\end{array}$ & $\begin{array}{l}\text { Corpus } \\
\text { striatum }\end{array}$ & Hemispheres & Diencephalon & $\begin{array}{l}\text { Lower } \\
\text { brain stem }\end{array}$ \\
\hline Control & $89 \pm 4(16)$ & $49 \pm 3(16)$ & $48 \pm 2(16)$ & $126 \pm 4(16)$ & $147 \pm 3(16)$ \\
DALA & $109 \pm 12(6)^{*}$ & $79 \pm 6(6)^{* * *}$ & $63 \pm 6(6)^{* *}$ & $155 \pm 14(6)^{* *}$ & $178 \pm 12(6)^{* * *}$ \\
DALA plus naloxone & $95 \pm 3(2)$ & $57 \pm 8(2)$ & $51 \pm 6(2)$ & $129 \pm 1(2)$ & $162 \pm 6(2)$ \\
FK 33-824 & $100 \pm 4(8)$ & $62 \pm 4(8)^{*}$ & $59 \pm 4(8)^{*}$ & $136 \pm 4(8)$ & $164 \pm 4(8)^{*}$ \\
FK 33-824 plus & $81 \pm 23(2)$ & $47 \pm 7(2)$ & $45 \pm 4(2)$ & $117 \pm 5(2)$ & $150 \pm 3(2)$ \\
$\quad$ naloxone & & & & &
\end{tabular}

Statistical significances were calculated according to one way analysis of variance followed by $t$-test. Differs from control: $* P<0.05$; ** $P<0.01$; *** $P<0.001$

\section{Effects of the Enkephalins}

and their Synthetic Analogues DALA

and FK 33-824 on the Utilization

of Dopamine, Noradrenaline and 5-HT

After inhibition of monoamine synthesis by benserazide, both $\mathrm{Met}^{5}$ - and $\mathrm{Leu}^{5}$-enkephalin significantly accelerated the disappearance of dopamine and had a similar though small and statistically nonsignificant effect on noradrenaline. Leu ${ }^{5}$-enkephalin increased the utilization of dopamine to a larger extent than did Met ${ }^{5}$-enkephalin $(34 \%$ vs. $18 \% ; P<0.025)$. For both opioid peptides the significantly accelerated disappearance of 5-HT was accompanied by simultaneous increases in 5-HIAA brain levels (Table 6). Similar results were obtained with the synthetic analogues DALA and FK 33-824 but at much lower dosage level. In contrast to the enkephalins these analogues sig- nificantly accelerated the disappearance of noradrenaline. The FK 33-824 compound did not accelerate the utilization of 5-HT but increased the 5-HIAA brain levels (Table 6).

\section{Behaviour of the Animals}

Both the enkephalins $(500 \mu \mathrm{g} / \mathrm{rat})$ and their synthetic analogues DALA $(4-250 \mu \mathrm{g} / \mathrm{rat})$ and FK 33-824 $(0.003-1 \mu \mathrm{g} / \mathrm{rat})$ induced a very similar morphine-like behavioural pattern, but with marked differences in potency for the different compounds. The i.c.v. injections of these peptides caused a loss of both the corneal and the eyelid reflexes, exophtalmus, analgesia (loss of tail-pinch reflex), salivation, catalepsy (akinesia) and catatonia (muscular hypertonus). They also caused acute episodes of wet-dog shaking behaviour 
Table 5. Effects of enkephalins and synthetic analogues D-Ala ${ }^{2}$-methionine enkephalin amide (DALA) and D-Ala ${ }^{2}, \mathrm{MePhe}^{4}, \mathrm{Met}_{(\mathrm{O})}{ }^{5}$-olenkephalin (FK 33-824) on the concentration of tryptophan in rat brain regions. The enkephalins (500 $\mu \mathrm{g} / \mathrm{rat})$ and the synthetic analogues DALA $(125 \mu \mathrm{g} / \mathrm{rat}$ ) and FK 33-824 (pooled data from $0.03,0.1,0.3$ and $1 \mu \mathrm{g} / \mathrm{rat}$ ) were injected intracerebroventricularly (i. c. v.) 10 min before NSD 1015 (3-hydroxybenzylhydrazine; $100 \mathrm{mg} / \mathrm{kg}$ i.p.) and the rats were killed after another $30 \mathrm{~min}$. Control rats received i.c.v. the same volume of saline $10 \mathrm{~min}$ before the NSD 1015. Naloxone $(10 \mathrm{mg} / \mathrm{kg})$ was given either s.c. $30 \mathrm{~min}$ before $\mathrm{Met}^{5}$-enkephalin or i.p. 60 min before Leu ${ }^{5}$-enkephalin or DALA. Shown are the means \pm S.E.M. with the number of experiments in parentheses

\begin{tabular}{|c|c|c|c|c|c|}
\hline \multirow[t]{2}{*}{ Enkephalin } & \multicolumn{5}{|c|}{ Tryptophan $(\mu \mathrm{g} / \mathrm{g})$} \\
\hline & $\begin{array}{l}\text { Limbic } \\
\text { regions }\end{array}$ & $\begin{array}{l}\text { Corpus } \\
\text { striatum }\end{array}$ & Hemispheres & Diencephalon & $\begin{array}{l}\text { Lower } \\
\text { brain stem }\end{array}$ \\
\hline Control & $4.6 \pm 0.1(20)$ & $4.7 \pm 0.1(20)$ & $4.7 \pm 0.1(20)$ & $4.9 \pm 0.1(20)$ & $4.4 \pm 0.1(20)$ \\
\hline $\begin{array}{l}\text { Met }^{5} \text {-enkephalin } \\
\text { Met }^{5} \text {-enkephalin plus }\end{array}$ & $5.6 \pm 0.2(6)^{* *}$ & $5.2 \pm 0.2(6)$ & $6.6 \pm 0.3(6)^{* * *}$ & $6.7 \pm 0.4(6)^{* * *}$ & $6.4 \pm 0.4(6)^{* * * *}$ \\
\hline naloxone & $4.6 \pm 0.6(2)$ & $5.3 \pm 0.2(2)$ & $5.0 \pm 0.6(2)$ & $5.8 \pm 0.4(2)$ & $6.4 \pm 0.4(2)^{* * *}$ \\
\hline Leu $^{5}$-enkephalin & $6.0 \pm 0.2(4)^{* * *}$ & $5.4 \pm 0.2(4)^{*}$ & $5.9 \pm 0.2(4)^{* *}$ & $6.7 \pm 0.2(4)^{* * *}$ & $5.8 \pm 0.1(4)^{* * *}$ \\
\hline $\begin{array}{l}\mathrm{Leu}^{5} \text {-enkephalin plus } \\
\text { naloxone }\end{array}$ & $5.3 \pm 0.1(2)$ & $4.7 \pm 0.3(2)$ & $5.8 \pm 0.2(2)^{*}$ & $6.1 \pm 0.4(2)^{*}$ & $5.5 \pm 0.4(2)^{*}$ \\
\hline DALA & $5.6 \pm 0.6(6)^{* *}$ & $5.7 \pm 0.5(6)^{* * *}$ & $5.7 \pm 0.7(6)^{* *}$ & $6.0 \pm 0.7(6)^{* *}$ & $5.4 \pm 0.5(6)^{* * *}$ \\
\hline DALA plus naloxone & $4.8 \pm 0.2(2)$ & $5.3 \pm 0.1(2)$ & $5.5 \pm 0.3(2)$ & $5.3 \pm 0.6(2)$ & $4.6 \pm 0.5(2)$ \\
\hline FK $33-824$ & $5.4 \pm 0.2(8)^{*}$ & $5.0 \pm 0.1$ & $5.3 \pm 0.1(8)$ & $5.4 \pm 0.1(8)$ & $4.5 \pm 0.2(8)$ \\
\hline
\end{tabular}

Statistical significances were calculated according to one way analysis of variance followed by $t$-test. Differs from control: $* P<0.05$; ** $P<0.01 ; * * * P<0.001$

Table 6. Effects of enkephalins and synthetic analogues D-Ala ${ }^{2}$-methionine enkephalin amide (DALA) and D-Ala ${ }^{2}, \mathrm{MePhe}{ }^{4}, \mathrm{Met}(\mathrm{O})^{5}-\mathrm{ol}-$ enkephalin (FK 33-824) on monoamine and 5-hydroxyindoleacetic acid (5-HIAA) levels in whole rat brain after synthesis inhibition. All rats received benserazide $(800 \mathrm{mg} / \mathrm{kg}$, i.p.) and immediately afterwards the enkephalins $(500 \mu \mathrm{g} / \mathrm{rat})$ or the synthetic analogues DALA (50 $\mu \mathrm{g} / \mathrm{rat})$ and FK 33-824 (1 $\mu \mathrm{g} / \mathrm{rat}$ ) were injected intracerebroventricularly (i.c.v.) (half of the dose into each lateral ventricle) followed within $25 \mathrm{~min}$ by the $40 \%$ of the first dose (half of the dose into each lateral ventricle). The animals were killed $60 \mathrm{~min}$ after benserazide. Control rats received i.c. v. the same volume of saline after pretreatment with benserazide as above. Shown are the means $(\mathrm{ng} / \mathrm{g}) \pm$ S.E.M. of $4-5$ determinations

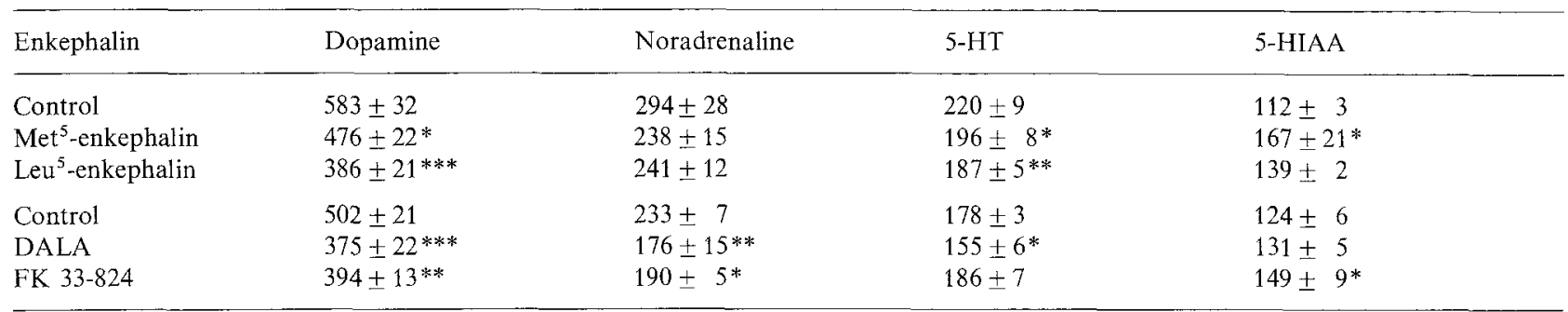

Differs from the respective control: $* P<0.05 ; * * P<0.01$; *** $P<0.001$ (one way analysis of variance followed by $t$-test)

and especially after large doses of DALA $(125 \mu \mathrm{g} / \mathrm{rat})$ rotational behaviour (barrel rotation). For the two synthetic analogues this behavioural pattern was longlasting (more than $40 \mathrm{~min}$ ). As already mentioned the differences in potency were very striking; even a dose as low as $3 \mathrm{ng} / \mathrm{rat}$ of the FK 33-824 compound clearly induced a loss of the corneal reflex, exophtalmus, piloerection and cataleptic postures in some of the rats. It should be mentioned that FK 33-824, the most potent opioid peptide studied, caused the same behavioural pattern also after systemic administration $(5 \mathrm{mg} / \mathrm{kg}$; s.c.). Naloxone $(1 \mathrm{mg} / \mathrm{kg}$; s.c.) was able not only to prevent but also to reverse within 2 min all the fully developed behavioural manifestations induced by a large dose of DALA ( $250 \mu \mathrm{g} / \mathrm{rat}$; i.c. v.).

\section{Discussion}

The intracerebroventricular administration of $\mathrm{Met}^{5}$ and $\mathrm{Leu}^{5}$-enkephalin or their more stable analogues
DALA and FK 33-824 stimulated the synthesis of dopamine, noradrenaline and 5-hydroxytryptamine by naloxone-sensitive mechanisms, and their utilization after inhibition of synthesis. Therefore, it is tempting to conclude that endogenous enkephalins, through the activation of opiate receptors, are involved in the shortterm regulation of central monoaminergic systems. Further evidence is provided by the fact that the acute administration of the pure opiate receptor antagonists, naloxone and naltrexone, decreased the brain dopamine and 5-hydroxytryptamine synthesis (cf. GarciaSevilla et al., 1978).

The enkephalins and their synthetic analogues DALA and FK 33-824 enhanced the formation of DOPA by a naloxone-sensitive mechanism, both in the dopamine- and noradrenaline-rich areas of the brain. These results confirm and extend recent findings showing a naloxone-sensitive increase in the synthesis of dopamine in the caudate nucleus after the i.c.v. in- 
jection of DALA (Biggio et al., 1978). As expected, the opioid peptides showed marked differences in potency in stimulating brain catecholamine synthesis. It has been reported that the breakdown of both $\mathrm{Met}^{5}$ - and $\mathrm{Leu}^{5}$-enkephalin by brain peptidases is entremely rapid (Meek et al., 1977; Dupont et al., 1977), which, in turn, may account for the relatively large doses $(500 \mu \mathrm{g} / \mathrm{rat})$ needed for behavioural and biochemical effects. However, the low potency of the enkephalins can be increased after chemical manipulation of the $\mathrm{Met}^{5}$ enkephalin molecule. The replacement of glycine ${ }^{2}$ by Dalanine and amidation of the C-terminal carboxyl group (DALA), or the replacement of glycine ${ }^{2}$ by Dalanine together with $\mathrm{N}$-methylation of the phenylalanine residue and the transformation of the methionine to methioninol sulphoxide (FK 33-824), protect against peptidase activity (Pert et al., 1976; Roemer et al., 1977) and the resulting enkephalin analogues show a considerable increase in potency. Thus, the analogues DALA and FK $33-824$ were $10^{2}-10^{5}$ times more potent than the enkephalins in stimulating tyrosine hydroxylase activity in vivo. This neurochemical effect of the enkephalins was particularly striking in the dopamine-predominant parts of the brain, i.e. the limbic forebrain and the corpus striatum, where the doses of FK 33-824 required to increase the formation of DOPA were in the nanogram range (see Fig. 2). This extremely potent enkephalin analogue proved active also after systemic administration in agreement with published data (Roemer et al., 1977), indicating that the modification of the $\mathrm{Met}^{5}$-enkephalin molecule also enables penetration through the blood-brain barrier. Both $\mathrm{Met}^{5}$ - and Leu ${ }^{5}$-enkephalin markedly increased the brain tyrosine concentration but this effect was not antagonized by naloxone, indicating that opiate receptors were not involved. It is unlikely that such an unspecific effect accounts for the specific increases (i. e. blocked by naloxone) in catecholamine synthesis induced by the enkephalins. In fact, it has been reported that the first step in the enzymatic breakdown of enkephalins is the split of the Tyr-Gly amide bond, releasing free tyrosine (Meek et al., 1977; Dupont et al., 1977). The tyrosine released from the administered peptide might well explain the marked increases in brain tyrosine observed here and by others (Calderini et al., 1978) and the lack of antagonism by naloxone. In support of this possibility it was found that the two enzyme resistant analogues DALA and FK 33-824 did not increase the brain tyrosine concentration (see Table 2). In the various brain regions, the increases in tyrosine concentrations induced by $\mathrm{Met}^{5}$-enkephalin $(85-140 \%)$ were higher than those of $\mathrm{Leu}^{5}$-enkephalin $(50-70 \%)$, suggesting that the former peptide was more rapidly inactivated by enzymatic cleavage, which may explain its lower activity on DOPA formation (see Tables 1 and 2).

It has recently been reported that $\mathrm{Met}^{5}$-enkephalin decreases both the brain dopamine and noradrenaline turnover, while the synthetic analogue DALA increases that of dopamine without affecting noradrenaline turnover (Calderini et al., 1978). As discussed by these authors, however, the decrease in the catecholamine turnover induced by $\mathrm{Met}^{5}$-enkephalin might be an artifact involving an isotopic dilution effect, since the measurement of the changes in turnover were based on the apparent conversion of ${ }^{3} \mathrm{H}$-tyrosine into dopamine and noradrenaline during a simultaneous increase in brain tyrosine concentration induced by the peptide. When this difficulty was circumvented by measuring the accumulation of DOPA after decarboxylase inhibition, we found that both $\mathrm{Met}^{5}$-enkephalin and DALA increased catecholamine synthesis and metabolism independently of the brain tyrosine concentration.

The enkephalins also enhanced the formation of 5HTP and the brain tryptophan concentration, but these effects were at most only partially blocked by naloxone. Therefore, the possibility that the simultaneous increases in tryptophan concentration may secondarily affect the synthesis of 5-HT has to be considered. However, we cannot discard a stimulating action of the enkephalins on 5-HT neurons as indicated by the enhanced depletion after inhibition of synthesis by benserazide. In contrast to the enkephalins, the DALA analogue increased the accumulation of 5-HTP and the concentration of cerebral tryptophan by naloxonesensitive mechanisms. As the utilization of 5-HT was also accelerated, a specific effect on serotoninergic neurons seems to be involved. However, a comparatively large dose of DALA $(125 \mu \mathrm{g} / \mathrm{rat})$ was needed to enhance brain 5-HT turnover. Since DALA stimulated the formation of DOPA at a much lower dosage level $(4 \mu \mathrm{g} / \mathrm{rat})$ a more selective action of the enkephalins on catecholaminergic neurons can be suggested.

The gross behavioural profiles induced by the enkephalins and synthetic analogues showed a close similarity with those induced by morphine and other opiated (García-Sevilla et al., 1978; Browne et al., 1979), suggesting the involvement of common mechanisms. However, whether or not this behavioural pattern is correlated with the enkephalins-induced changes in brain monoamines remains to be elucidated.

Finally, the neurochemical results do not give any indication where the opiate receptors, responsible for the increased monoamine synthesis, are situated. It has been reported, however, that the naloxone-sensitive stimulating effect of DALA on DOPA formation in the caudate nucleus persists after destruction of striatal dopamine receptors with kainic acid, suggesting that 
the opiate receptors which mediate this effect are located on dopaminergic nerve terminals (Biggio et al., 1978). It is known that presynaptic opiate receptors are involved in the regulation of transmitter release in the central nervous system. In fact, the existence of presynaptic inhibitory opiate receptors both in dopaminergic (Loh et al., 1976) and noradrenergic (Taube et al., 1977) nerve terminals have been described. Therefore, it is possible that the observed increased monoamine synthesis induced by the enkephalins might be the compensatory mechanism for a decreased release of dopamine and noradrenaline induced by the opioid peptides.

Acknowledgements. This study was supported by grants from the Swedish Medical Research Council (No. 155). J. A. García-Sevilla was supported by a research grant from the Juan March Foundation, Madrid, Spain.

\section{References}

Andén, N.-E., Corrodi, H., Fuxe, K.: Turnover studies using synthesis inhibition. In: Metabolism of amines in the brain $(\mathrm{G}$. Hooper, ed.), pp. 38-47. London: McMillan 1969

Andén, N.-E., Fuxe, K., Hökfelt, T.: Effect of some drugs on central monoamine nerve terminals lacking nerve impulse flow. Eur. J. Pharmacol. 1, 226-232 (1967)

Atack, C. V.: The determination of dopamine by a modification of the dihydroxyindole fluorimetric assay. Br. J. Pharmacol. 48, $699-714$ (1973)

Atack, C., Lindquist, M.: Conjoint native and orthophthaldialdehyde-condensate assays for the fluorimetric determination of 5-hydroxyindoles in brain. Naunyn-Schmiedeberg's Arch. Pharmacol. 279, 267-284 (1973)

Atack, C., Magnusson, T.: A procedure for the isolation of noradrenaline (together with adrenaline), dopamine, 5-hydroxytryptamine and histamine from the same sample using a simple column of strongly acidic cation exchange resin. Acta Pharmacol. Toxicol. (Kbh.) 42, 35-57 (1978)

Bédard, P., Carlsson, A., Lindqvist, M.: Effect of a transverse cerebral hemisection on 5-hydroxytryptamine metabolism in the rat brain. Naunyn-Schmiedeberg's Arch. Pharmacol. 272, 1-15 (1972)

Bertler, $\AA$., Carlsson, A., Rosengren, E.: A method for the fluorimetric determination of adrenaline and noradrenaline in tissues. Acta Physiol. Scand. 44, 273-292 (1958)

Biggio, G., Casu, M., Corda, M. G., Di Bello, C., Gessa, G. L.: Stimulation of dopamine synthesis in caudate nucleus by intrastriatal enkephalins and antagonism by naloxone. Science 200, 552-554 (1978)

Browne, R. G., Derrington, D. C., Segal, D. S.: Comparison of opiate- and opioid-peptide-induced immobility. Life Sci. 24, $933-942$ (1979)

Calderini, G., Consolazione, A., Garattini, S., Algeri, S.: Different effects of methionine-enkephalin and (D-Ala ${ }^{2}$ ) methionineenkephalin amide on the metabolism of dopamine and norepinephrine in rat brain. Brain Res. 146, $392-399$ (1978)

Carlsson, A., Lindquist, M. : Effect of ethanol on the hydroxylation of tyrosine and tryptophan in rat brain in vivo. J. Pharm. Pharmacol. 25, 437-440 (1973)

Carlsson, A., Davies, J. N., Kehr, W., Lindqvist, M., Atack, C. V.: Simultaneous measurement of tyrosine and tryptophan hydroxylase activities in brain in vivo using an inhibitor of the aromatic amino acid decarboxylase. Naunyn-Schmiedeberg's Arch. Pharmacol. 275, 153-168 (1972)

Dupont, A., Cusan, L., Garon, M., Alvarado-Urbina, G., Labrie, F.: Extremely rapid degradation of $\left[{ }^{3} \mathrm{H}\right]$ methionine-enkephalin by various rat tissues in vivo and in vitro. Life Sci. 21, 907-914 (1977)

Frederickson, R. C. A.: Enkephalin pentapeptides - A review of current evidence for a physiological role in vertebrate neurotransmission. Life Sci. 21, 23-42 (1977)

Garcia-Sevilla, J. A., Ahtee, L., Magnusson, T., Carlsson, A.: Opiate-receptor mediated changes in monoamine synthesis in rat brain. J. Pharm. Pharmacol. 30, 613-621 (1978)

Henderson, G., Hughes, J., Kosterlitz, H. W.: In vitro release of Leuand Met-enkephalin from the corpus striatum. Nature 271, $677-679$ (1978)

Hong, J. S., Yang, H.-Y. T., Fratta, W., Costa, E.: Determination of methionine enkephalin in discrete regions of rat brain. Brain Res. 134, 383-386 (1977)

Hughes, J., Smith, T. W., Kosterlitz, H. W., Fothergill, L. A., Morgan, B. A., Morris, H. R.: Identification of two related pentapeptides from the brain with potent opiate agonist activity. Nature 258, 577-579 (1975)

Hughes, J., Kosterlitz, H. W., Smith, T. W.: The distribution of methionine-enkephalin and leucine-enkephalin in the brain and peripheral tissues. Br. J. Pharmacol. 61, 639-647 (1977)

Iversen, L. L., Iversen, S. D., Bloom, F. E., Vargo, T., Guillemin, R. : Release of enkephalin from rat globus pallidus in vitro. Nature 271, 679-681 (1978)

Kehr, W., Carlsson, A., Lindquist, M.: A method for the determination of 3,4-dihydroxyphenylalanine (Dopa) in brain. Naunyn-Schmiedeberg's Arch. Pharmacol. 274, 273-280(1972)

Kehr, W., Lindqvist, M., Carlsson, A.: Distribution of dopamine in the rat cerebral cortex. J. Neural Transm. 38, 173-180 (1976)

Kuschinsky, K. : Actions of narcotics on brain dopamine metabolism and their relevance for psychomotor effects. Arzneim.-Forsch. (Drug Res.) 26, 563-567 (1976)

Loh, H. H., Brase, D. A., Sampath-Khanna, S., Mar, J. B., Way, E. L., Li, C. H.: Endorphin in vitro inhibition of striatal dopamine release. Nature 264, 567-568 (1976)

Meek, J. L., Yang, H.-Y. T., Costa, E..: Enkephalin catabolism in vitro and in vivo. Neuropharmacology 16, 151-154 (1977)

Osborne, H., Höllt, V., Herz, A.: Subcellular distribution of enkephalins and endogenous opioid activity in rat brain. Life Sci. 22, $611-618(1978 \mathrm{a})$

Osborne, H., Höllt, V., Herz, A.: Potassium-induced release of enkephalins from rat striatal slices. Eur. J. Pharmacol. 48, 219221 (1978b)

Pert, C. B., Pert, A., Chang, J. K., Fong, B. T. W.: D-Ala ${ }^{2}$-metenkephalinamide: A potent long-lasting synthetic pentapeptide analgesic. Science 194, 330-332 (1976)

Roemer, D., Buescher, H. H., Hill, R. C., Pless, J., Bauer, W., Cardinaux, F., Closse, A., Hauser, "D., Huguenin, R.: A synthetic enkephalin analogue with prolonged parenteral and oral analgesic activity. Nature 268, 547-549 (1977)

Snyder, S. H., Simantov, R. :The opiate receptor and opioid peptides. J. Neurochem. 28, 13-20 (1977)

Taube, H. D., Starke, K., Borowski, E. : Presynaptic receptor systems on the noradrenergic neurons of rat brain. NaunynSchmiedeberg's Arch. Pharmacol. 299, 123-141 (1977)

Waalkes, T. P., Udenfriend, S.: A fluorimetric method for the estimation of tyrosine in plasma and tissues. J. Lab. Clin. Med. 50, $733-736$ (1957)

Received July 26/Accepted October 17, 1979 